\title{
KARAKTERISTIK KADER POSYANDU DALAM UPAYA DETEKSI DINI KANKER SERVIKS
}

\author{
Lilik Hanifah ${ }^{1, *}$, Ajeng Novita Sari $^{2}$ \\ ${ }^{1}$ STIKES Mamba'ul 'Ulum Surakarta \\ ${ }^{2}$ Politeknik Santo Paulus Surakarta \\ ${ }^{1}$ lilik_hanifah84@yahoo.com*
}

\begin{abstract}
Abstrak
Latar Belakang : Kanker serviks merupakan suatu keganasan yang disebabkan oleh adanya pertumbuhan sel-sel epitel serviks yang tidak terkontrol. Pencegahan kanker serviks dapat dilakukan dengan melalukan pemeriksaan kesehatan serviks secara dini (skrining), karena gejala kanker serviks tidak terlihat sampai stadium yang lebih parah
\end{abstract}

Tujuan : Penelitian ini bertujuan untuk mengetahui karakteristik kader posyandu dalam upaya deteksi dini kanker serviks

Metode : Penelitian ini merupakan penelitian survey analitik dengan pendekatan cross sectional. Populasi penelitian ini adalah seluruh kader posyandu di Mojosongo Jebres Surakarta. Teknik sampling yang digunakan adalah actidental sampling pada kader posyandu yang hadir pada kegiatan refresing kader yaitu sejumlah 46 kader posyandu. Alat pengumpulan data berupa angket. Analisa data dalam penelitian ini menggunakan distribusi frekuensi.

Hasil : Kader posyandu mayoritas melakukan deteksi dini kanker servik baik melalui iva tes maupun papsmear sejumlah 32 orang $(69,6 \%)$. Karakteristik usia responden adalah mayoritas usia reproduktif yaitu 30 orang $(65,2 \%)$ pendidikan responden mayoritas adalah pendidikan menengah yaitu 25 orang $(54,3 \%)$, pekerjaan responden mayoritas adalah tidak bekerja yaitu 39 orang $(84,8 \%)$ dan paritas responden adalah mayoritas memiliki $1-2$ anak yaitu 27 orang (58,7\%). Kader posyandu yang melakukan deteksi dini kanker servik mayoritas pada usia reproduktif yaitu 18 orang $(56,2 \%)$, mayoritas pada pendidikan menengah yaitu 18 orang $(56,3 \%)$, mayoritas pada kader posyandu yang tidak bekerja yaitu 28 orang $(87,5 \%)$ dan mayoritas pada paritas $1-2$ anak yaitu 17 orang $(53,1 \%)$.

Simpulan: Karakteristik kader posyandu yang melakukan deteksi dini kanker servik adalah mayoritas pada usia reproduktif, pendidikan menengah, kader posyandu yang tidak bekerja dan memiliki paritas $1-2$ anak.

Kata kunci: Karakteristik; Kader Posyandu; Deteksi Dini kanker Serviks

\section{CHARACTERISTICS OF POSYANDU CADRES IN EFFORT EARLY DETECTION OF CANCER SERVICES}

\footnotetext{
Abstract

Background: Cervical cancer is a malignancy caused by uncontrolled growth of cervical epithelial cells. Prevention of cervical cancer can be done by doing cervical health checks early (screening), because the symptoms of cervical cancer are not visible until a more severe stage
} 
The Purpose : This study aims to to determine the characteristics of posyandu cadres in the early detection of cervical cancer.

Method: This research is an analytic survey research with cross sectional approach. The population of this research is all posyandu cadres in Mojosongo Jebres Surakarta. The sampling technique used was accidental sampling of posyandu cadres present at the cadre refresing activity, which were 46 posyandu cadres. Data collection tool in the form of a questionnaire. Analysis of the data in this study uses a frequency distribution.

Result: The majority of posyandu cadres performed early detection of cervical cancer through iva tests and pap smears totaling 32 people (69.6\%). Characteristics of the age of respondents is the majority of reproductive age that is 30 people $(65.2 \%)$ the education of the majority of respondents was secondary education of 25 people (54.3\%), the work of the majority of respondents was unemployed ie 39 people $(84.8 \%)$ and the parity of respondents is the majority have 1-2 children, namely 27 people (58.7\%). Posyandu cadres who did early detection of cervical cancer predominantly at reproductive age were 18 people (56.2\%), the majority in secondary education is 18 people $(56.3 \%)$, the majority of posyandu cadres who did not work were 28 people (87.5\%) and the majority in parity 1 - 2 children were 17 people (53.1\%).

Conclusion: The characteristics of posyandu cadres who do early detection of cervical cancer are the majority at reproductive age, secondary education, posyandu cadres who do not work and have a parity of 1-2 children.

Key words: Characteristics; Posyandu Cadre; Early Detection of Cervical Cancer

\section{PENDAHULUAN}

Kanker serviks merupakan suatu keganasan yang disebabkan oleh adanya pertumbuhan sel-sel epitel serviks yang tidak terkontrol. Berdasarkan data dari World Health Organization (WHO) pada tahun 2012, kanker serviks merupakan jenis kanker keempat yang paling sering ditemukan pada wanita. Sebanyak 528.000 kasus baru dan 266.000 kematian ditemukan di seluruh dunia dan lebih dari $85 \%$ berasal dari negara berkembang termasuk Indonesia (WHO, 2013). Kanker serviks menempati urutan kedua setelah kanker payudara sebagai kanker yang paling sering diderita wanita Indonesia. Data dari GLOBOCAN menunjukkan bahwa terdapat 20.928 kasus baru dan 9.928 kematian ditemukan di Indonesia pada tahun 2012 (GLOBOCAN, 2012)

Kanker serviks menempati posisi kedua penderita terbanyak (16 per 100.000 perempuan) setelah kanker payudara (38 per 100.000perempuan) (IARC, 2012) dalam (Kemenkes RI, 2015). Menurut profil kesehatan Provinsi Jawa Tengah tahun 2015, kanker serviks merupakan kanker tertinggi perempuan kedua di dunia maupun di Indonesia.Kanker tersebut menjadi salah satu masalah utama pada kesehatan perempuan di dunia, terutama pada negara berkembang yang mempunyai sumber daya terbatas seperti di Indonesia. Tingginya prevalensi kanker di Indonesia perlu dicermati dengan tindakan pencegahanyang telah dilakukan oleh penyedia layanan kesehatan. Pencegahan kanker serviks dapat 
dilakukan dengan melalukan pemeriksaan kesehatan serviks secara dini (skrining), karena gejala kanker serviks tidak terlihat sampai stadium yang lebih parah (Juanda, 2015).

Menurut Profil Kesehatan Provinsi Jawa Tengah tahun 2015, jumlah WUS yang dilakukan deteksi dini IVA di Jawa Tengah tahun 2015 yang dilaporkan sebanyak 18.954 WUS atau 0,30 persen. Persentase WUS ini masih sangat jauh dari target yang ditetapkan sebesar 10 persen. Jumlah 18.954 WUS yang dilakukan IVA test, ditemukan IVA positif pada 1.868 WUS atau 9,86 persen, angka ini lebih tinggi dari yang ditetapkan oleh kementerian kesehatan yaitu 3 persen (Dinkes Prov Jateng, 2015).

Dewasa ini sudah dikenal beberapa metode deteksi dini kanker serviks yaitu tes pap smear, IVA, pembesaran IVA dengan gineskopi, kolkoskopi, servikografi, thin prep dan tes HPV. Namun yang sesuai dengan kondisi di negara berkembang termasuk Indonesia adalah dengan menggunakan metode IVA, karena tekniknya mudah dan sederhana, biayanya murah, tingkat sensitifitasnya tinggi, cepat serta cukup akurat untuk menemukan kelainan pada tahap kelainan sel (Displasia) atau sebelum pra kanker. Namun, kurangnya kesadaran dari wanita usia subur untuk melakukan deteksi dini kanker serviks menjadikan pemeriksaan IVA ini kurang diminati (Fauziah, 2011).

Belum tercapainya target deteksi dini kanker servik disebabkan oleh kurangnya kesadaran wanita untuk mengikuti deteksi dini, dimana karakteristik seseorang berkaitan dengan kebiasaan atau perilaku yang dilakukan. Penelitian ini didukung oleh penelitian dari Nurtini (2016), dengan hasil penelitian didapatkan gambaran karakteristik wanita usia subur (WUS) yang mengikuti tes Inspeksi Visual Asam Asetat (IVA) sebagai berikut :WUS dengan karakteristik umur yang mengikuti tes IVA adalah 25-56 tahun, WUS terbanyak dengan pendidikan terakhir Sekolah Menengah Atas (SMA), WUS mayoritas responden memiliki pendapatan keluarga perbulan dibawah UMK, WUS menikah mayoritas diatas usia 20 tahun, WUS mayoritas memiliki pengetahuan baik, WUS mayoritas menggunakan kontrasepsi IUD pada saat pemeriksaan IVA dengan lama pemakaian tidak lebih dari 5 tahun, WUS mayoritas paritas 2, Hasil pemeriksaan IVA, 5 orang dari 27 orang WUS yang dinyatakan hasil IVA nya positif.

Berdasarkan uraian di atas, penulis tertarik untuk melakukan penelitian tentang "Karakteristik Kader Posyandu Dalam Upaya Deteksi Dini Kanker Servik," dimana kanker serviks merupakan kanker dengan insiden cukup tinggi pada wanita Indonesia. Hal tersebut menjadikan alasan mengapa deteksi dini atau penapisan terhadap kanker leher rahim sangat penting. Saat ini penapisan merupakan upaya terbaik dalam menangani kanker serviks, mengingat tidak sedikit beban kesehatan yang dikeluarkan untuk menangani kanker ini (Fauziah, 2011).

\section{METODE}

Penelitian ini merupakan penelitian survey analitik dengan pendekatan cross sectional. Populasi penelitian ini adalah seluruh kader posyandu di Mojosongo Jebres Surakarta. Teknik sampling yang digunakan adalah actidental sampling 
pada kader posyandu yang hadir pada kegiatan refresing kader yaitu sejumlah 46 kader posyandu.

Pada penelitian ini menggunakan alat pengumpulan data berupa angket. Metode pengumpulan data yang digunakan adalah pengumpulan data primer. Dalam penelitian ini pengumpulan data primer dilakukan dengan membagikan angket secara langsung kepada kader posyandu. Analisa data dalam penelitian ini menggunakan distribusi frekuensi.

\section{HASIL DAN PEMBAHASAN}

Tabel 1. Distribusi Frekuensi Perilaku Deteksi Dini Kanker Servik

\begin{tabular}{|c|c|c|}
\hline Deteksi Dini Kanker Servik & Frekuensi (f) & Prosentase $(\%)$ \\
\hline Iva Tes / Pap Smear & 32 & 69,6 \\
\hline $\begin{array}{l}\text { Tidak pernah melakukan } \\
\text { pemeriksaan iva tes / pap smear }\end{array}$ & 14 & 30,4 \\
\hline Total & 46 & 100 \\
\hline
\end{tabular}

Tabel 2 diatas menunjukkan bahwa kader posyandu mayoritas melakukan deteksi dini kanker servik baik melalui iva tes maupun papsmear sejumlah 32 orang $(69,6 \%)$.

Tabel 2. Distribusi Frekwensi Karakteristik Kader Posyandu

\begin{tabular}{lcc}
\hline \multicolumn{1}{c}{ Karakteristik } & Frekwensi (f) & Prosentase (\%) \\
\hline Usia & 30 & \\
Usia Reproduktif & 16 & 65,2 \\
Usia Non Reproduktif & 46 & 34,8 \\
Total & 12 & 100 \\
\hline Pendidikan & 12 & 26,1 \\
Dasar & 25 & 54,3 \\
Menengah & 9 & 19,6 \\
Tinggi & 46 & 100 \\
Total & & \\
\hline Pekerjaan & 7 & 15,2 \\
Bekerja & 39 & 84,8 \\
Tidak Bekerja & 46 & 100 \\
Total & & \\
\hline Paritas & 27 & 58,7 \\
1 - anak & 19 & 41,3 \\
2 anak & 46 & 100 \\
\hline
\end{tabular}

Berdasarkan Tabel 2. menunjukkan karakteristik usia responden adalah mayoritas usia reproduktif yaitu 30 orang $(65,2 \%)$ pendidikan responden mayoritas adalah pendidikan menengah yaitu 25 orang $(54,3 \%)$, karakteristik pekerjaan responden mayoritas adalah tidak bekerja yaitu 39 orang $(84,8 \%)$ dan paritas responden adalah mayoritas memiliki $1-2$ anak yaitu 27 orang $(58,7 \%)$. 
Tabel 3 Karakteristik Kader Posyandu Dalam Upaya Deteksi Dini Kanker Servik

\begin{tabular}{|c|c|c|c|c|c|c|}
\hline \multirow{3}{*}{$\begin{array}{l}\text { Karakteristik Kader } \\
\text { Posyandu }\end{array}$} & \multicolumn{4}{|c|}{ Deteksi Dini Kanker Servik } & \multirow[t]{3}{*}{ Total } & \multirow[t]{3}{*}{$(\%)$} \\
\hline & \multicolumn{2}{|c|}{ Iva Tes/Pap Smear } & \multicolumn{2}{|c|}{$\begin{array}{c}\text { Tidak Pernah Melakukan } \\
\text { Pemeriksaan }\end{array}$} & & \\
\hline & (f) & $(\%)$ & (f) & $(\%)$ & & \\
\hline \multicolumn{7}{|l|}{ Usia } \\
\hline Usia Reproduktif & 18 & 56,2 & 12 & 85,7 & 30 & 65,2 \\
\hline Usia Non Reproduktif & 14 & 43,8 & 2 & 14,3 & 16 & 34,8 \\
\hline Total & 32 & 100 & 14 & 100 & 46 & 100 \\
\hline \multicolumn{7}{|l|}{ Pendidikan } \\
\hline Dasar & 9 & 28,1 & 3 & 21,4 & 12 & 26,1 \\
\hline Menengah & 18 & 56,3 & 7 & 50,0 & 25 & 54,3 \\
\hline Tinggi & 5 & 15,6 & 4 & 28,6 & 9 & 19,6 \\
\hline Total & 32 & 100 & 14 & 100 & 46 & 100 \\
\hline \multicolumn{7}{|l|}{ Pekerjaan } \\
\hline Bekerja & 4 & 12,5 & 3 & 21,4 & 7 & 15,2 \\
\hline Tidak Bekerja & 28 & 87,5 & 11 & 78,6 & 39 & 84,8 \\
\hline Total & 32 & 100 & 14 & 100 & 46 & 100 \\
\hline \multicolumn{7}{|l|}{ Paritas } \\
\hline $1-2$ anak & 17 & 53,1 & 10 & 71,4 & 27 & 58,7 \\
\hline$>2$ anak & 15 & 46,9 & 4 & 28,6 & 19 & 41,3 \\
\hline Total & 32 & 100 & 14 & 100 & 100 & 100 \\
\hline
\end{tabular}

Berdasarkan tabel 3 diketahui bahwa kader posyandu yang melakukan deteksi dini kanker servik mayoritas pada usia reproduktif yaitu 18 orang $(56,2 \%)$, mayoritas pada pendidikan menengah yaitu 18 orang $(56,3 \%)$, mayoritas pada responden yang tidak bekerja yaitu 28 orang $(87,5 \%)$ dan mayoritas pada paritas 1 -2 anak yaitu 17 orang $(53,1 \%)$.

Berdasarkan Tabel 1. Dapat diketahui bahwa mayoritas kader posyandu melakukan deteksi dini kanker servik baik melalui pemeriksaan iva tes maupun papsmear. Perilaku kesehatan pada dasarnya adalah suatu respon seseorang terhadap stimulus yang berkaitan dengan sakit dan penyakit, pada sistem pelayanan kesehatan, makanan serta lingkungan. Perilaku dapat diartikan sebagai kegiatan atau aktivitas seseorang atau organisasi yang bersangkutan. Deteksi dini kanker serviks dalam penelitian ini adalah tindakan nyata responden dalam usaha untuk pencegahan dini kanker serviks (Notoatmodjo, 2010).

Pada tabel 2 menunjukkan mayoritas kader posyandu dalam usia reproduktif. Umur merupakan salah satu variabel yang penting karena banyak penyakit ditemukan yang berpatokan pada umur. Risiko tinggi infeksi HPV sangat umum terjadi pada wanita dengan usia muda. Sebagian kecil persentase dari semua infeksi virus HPV berkembang menjadi kanker. Deteksi dini kanker serviks dapat dilakukan pada semua usia namun dengan beberapa syarat yang disesuaikan dengan prosedur pelaksanaan pemeriksaan. WHO merekomendasikan untuk melakukan deteksi dini kanker serviks pada usia 30-49 tahun dimana pada masa ini apabila lesi pra-kanker ditemukan sejak dini maka akan menurunkan angka kejadian dan kematian akibat kanker serviks. Sebagian besar kader posyandu dengan pendidikan menengah, dimana pendidikan erat kaitannya dengan pengetahuan yang akan berpengaruh terhadap pola pikir seseorang terhadap kesehatan. Tingkat pendidikan masyarakat berkaitan dengan pemahaman 
informasi tentang kesehatan yang diterima masyarakat. Semakin tinggi tingkat pendidikan maka penerimaan terhadap informasi akan berbeda. Mayoritas kader posyandu tidak bekerja, dimana pekerjaan menjadi faktor penyebab seseorang untuk berperilaku terhadap kesehatannya. Hal ini disebabkan karena pekerjaan menjadi faktor risiko seorang mengalami sakit maupun penyakitnya. wanita yang tidak bekerja lebih banyak melakukan pemeriksaan kanker serviks daripada wanita yang bekerja, hal tersebut berkaitan dengan waktu dan pelayanan kesehatan. Berdasarkan jumlah anak responden, mayoritas memiliki 1 sampai 2 orang anak. Semakin sering seorang wanita melahirkan, maka semakin tinggi pula resiko terjadinya kanker serviks karena memiliki riwayat infeksi di daerah kelamin (Nurtini, 2016).

Pada tabel 3 menjelaskan bahwa mayoritas kader posyandu yang melakukan deteksi dini kanker servik adalah pada usia reproduktif yaitu usia 15 - 49 tahun, dimana pada penelitian ini sebagian besar kader posyandu yang melakukan deteksi dini kanker serviks adalah pada usia 30 - 40 tahun. Semakin cukup umur, tingkat kematangan dan kekuatan seseorang akan lebih matang dalam berfikir dan bekerja. Dari segi kepercayaan masyarakat seseorang yang lebih dewasa dipercaya dari orang yang belum tinggi kedewasaannya. (Wawan, 2011). Pada ibu yang berusia sekitar $30-40$ tahun memiliki tingkat kewaspadaan yang lebih tinggi untuk mencegah terjadinya kanker serviks. Semakin dini WUS memeriksakan diri maka secara dini akan diketahui adanya kanker serviks, hal ini sesuai dengan penelitian (Pangesti, 2012) yang menyatakan bahwa umur WUS yang melakukan pemeriksaan IVA sebagian besar adalah WUS yang berumur 30 - 40 tahun. Didukung juga oleh penelitian Ratnawati (2017) dengan hasil mayoritas WUS yang melakukan iva tes adalah pada usia 36 - 45 tahun yaitu sebesar $(66,7 \%)$. Kanker serviks merupakan kanker yang dapat memengaruhi para wanita dengan latar belakang dan umur yang berbeda di seluruh dunia. Jika ditarik rata-rata, kanker serviks sering kali menjangkiti dan dapat membunuh mereka pada usia produktif sekitar 30-50 tahun yang pada saat itu mereka masih memiliki tanggung jawab ekonomi dan sosial terhadap anak - anak maupun anggota keluarga lainnya (Tilong, 2012).

Berdasarkan karakteristik pendidikan, mayoritas kader posyandu yang melakukan deteksi dini kanker serviks adalah dengan pendidikan menengah. Orang yang berpendidikan tinggi akan memberi respon yang lebih rasional terhadap informasi yang datang dan akan berfikir sejauh mana keuntungan yang mungkin akan mereka peroleh dari gagasan tersebut (Wawan, 2011). Semakin tinggi tingkat pendidikan seseorang akan semakin luas pengetahuannnya. Semakin tinggi pengetahuan dan pemahaman terhadap kesehatan, akan meningkatkan pula cara pandang terhadap konsep sehat dan sakit menjadi mantap yang pada akhirnya akan mempengaruhi pandangan, cara hidup dan upaya seseorang untuk dapat meningkatkan derajat kesehatan (Setiyowati, 2011). Penelitian ini didukung oleh penelitian Ratnawati (2017) yang menyatakan bahwa mayoritas WUS yang melakukan IVA Tes adalah dengan pendidikan menengah. adalah pendidikan. Hal ini diperkuat juga oleh penelitian Nurtini (2016) dengan hasil penelitian menunjukkan bahwa mayoritas WUS yang mengikuti tes IVA berpendidikan menengah (SMA/sederajat). Pendidikan erat kaitannya dengan 
pengetahuan yang akan berpengaruh terhadap pola pikir seseorang terhadap kesehatan. Tingkat pendidikan masyarakat berkaitan dengan pemahaman informasi tentang kesehatan yang diterima masyarakat. Semakin tinggi tingkat pendidikan maka penerimaan terhadap informasi akan berbeda.

Pada karakteristik kader posyandu mayoritas yang melakukan deteksi dini kanker serviks adalah dengan kategori tidak bekerja atau sebagai ibu rumah tangga. Penelitian dari Ratnawati (2017) juga menyatakan bahwa mayoritas WUS yang melakukan pemeriksaan IVA Tes adalah tidak bekerja atau sebagai ibu rumah tangga yaitu $(63,3 \%)$. Penelitian ini sejalan dengan penelitian Maharsie dan Indarwati (2012) bahwa keikutsertaan ibu melakukan IVA Test berdasarkan pekerjaan ibu yaitu sebagian besar dilakukan oleh ibu rumah tangga yaitu sebanyak 16 reponden (42\%). Ibu mempunyai banyak waktu dan kesempatan untuk melakukan pemeriksaan IVA.

Sedangkan karakteristik kader poyandu berdasarkan paritas yang melakukan deteksi dini kanker serviks adalah mayoritas pada paritas $1-2$ anak. Hasil penelitian ini didukung oleh penelitian dari Pangesti (2010) yang menyatkan Karakteristik WUS yang melakukan pemeriksaan IVA di Puskesmas Karanganyar berdasarkan paritas / jumlah anak yang dilahirkan prosentase tertinggi adalah responden yang memiliki anak 2 yaitu 20 orang (26.3\%). Diperkuat juga oleh penelitian Nurtini (2012) berdasarkan jumlah anak responden, mayoritas memiliki 1 sampai 2 orang anak. Semakin sering seorang wanita melahirkan, maka semakin tinggi pula resiko terjadinya kanker serviks karena memiliki riwayat infeksi di daerah kelamin.

\section{SIMPULAN}

Karakteristik kader posyandu yang melakukan deteksi dini kanker servik adalah mayoritas pada usia reproduktif, sebagian besar denga pendidikan menengah, mayoritas pada kader posyandu yang tidak bekerja dan sebagian besar pada kader posyandu dengan paritas $1-2$.

\section{SARAN}

Bagi kader posyandu diharapkan untuk meningkatkan keikutsertaan dalam pemeriksaan iva tes maupun pap smear sebagai upaya deteksi dini kanker serviks, sedangkan bagi tenaga kesehatan diharapkan mampu meningkatkan penyuluhan kesehatan, sosialisasi dan pemeriksaan iva tes maupun pap smear sehingga dapat meningkatkan cakupan deteksi dini kanker serviks.

\section{DAFTAR PUSTAKA}

Dinas kesehatan Provinsi Jawa Tengah. 2015. Profil Kesehatan Provinsi Jawa tengah Tahun 2015. Jawa Tengah:Dinkes Provinsi Jawa Tengah

Fauziah, Ratri Manjari. 2011. Deteksi Dini Kanker Serviks pada Pusat Pelayanan Primer di Lima Wilayah DKI Jakarta. Jakarta: Artikel KesehatanVol. 61. No. 11. Hal. 447-453 
GLOBOCAN. Indonesia (2012) Estimated Cancer Mortality and Incidence All Ages : Female. [serial online]. Available from : URL : http://globocan.iarc.fr. Diunduh pada tanggal 10 Februari 2020

Juanda D dan Kesuma H. 2015. Pemeriksaan IVA (Inspeksi Visual Asam Asetat) Untuk Pencegahan Kanker Serviks. Jurnal Kedokteran dan Kesehatan 2(2) : $169-174$

Kemenkes RI. 2015. Panduan Program Nasional Gerakan Pencegahan dan Deteksi Dini Kanker Leher Rahim dan Kanker Payudara. Direktorat Pengendalian Penyakit Tidak Menular. Jakarta: Kemenkes RI.

Maharsie dan Indarwati. 2012. Hubungan Pengetahuan Tentang Kanker Serviks Dengan Keikutsertaan Ibu Melakukan IVA Test Di Kelurahan Jebres Surakarta. Gaster vol 9 no 2 Agustus 2012

Notoadmojo,S, 2010. Ilmu Perilaku Kesehatan. Jakarta : PT Rineka Cipta

Nurtini dkk. 2016. Karakteristik Wanita Usia Subur Yang Melakukan Inspeksi Visual Asam Asetat. JRKN Vol.01/No. 01/April-September/2017

Pangesti, N., Cokroaminoto,\&Nurlaila.(2010). Gambaran Karakteristik Wanita Usia Subur (Wus) yang Melakukan Pemeriksaan Inspeksi Visual Asam Asetat(IVA) Di Puskesmas Karanganyar. STIKES Muhammadiyah Gombong, Jurnal Ilmiah Kesehatan Keperawatan Volume 8 No.2 Juni 2012

Ratnawati A E dan Mudatin A. 2017. Gambaran Karakteristik Wanita Usia Subur Yang Telah Melakukan Pemeriksaan Inspeksi Visual Asam Asetat (Iva) Di Puskesmas Imogiri I Bantul Tahun 2017. Jurnal Ilmu Kebidanan, Jilid 4, Nomor 1, hlm 17-28

Setiyowati Rahardjo Dan Erna Kusumawati. 2011. Hubungan Tingkat Pendidikan Dan Pengetahuan Dengan Perilaku Keluarga Sadar Gizi (Kadarzi) Pada Masyarakat Perkotaan Dan Perdesaan Di Kabupaten Banyumas. Jurnal Kesmasindo. Volume 4, Nomor 2, Juli 2011, Hlm. 150-158

Tilong, A.D.2012.Bebas dari Ancaman Kanker Serviks. Yogyakarta:Flashbooks.

Wawan, A dan Dewi, M. 2011. Pengetahuan Sikap dan Perilaku Manusia. Yogyakarta: Nuha Medika

World Health Organization (WHO). 2013. Global Cancer Burden Rises TO 14.1 Million New Cases in 2012 : Marked increase in breasts cancers must be addressed. Switzerland : WHO 